\title{
完善技能大赛赛事体系 弘扬新时代工匠精神
}

\section{Improving the Skill Competition System, Promoting the Spirit of Craftsmen in the New Era 徐秀林}

Xiulin Xu

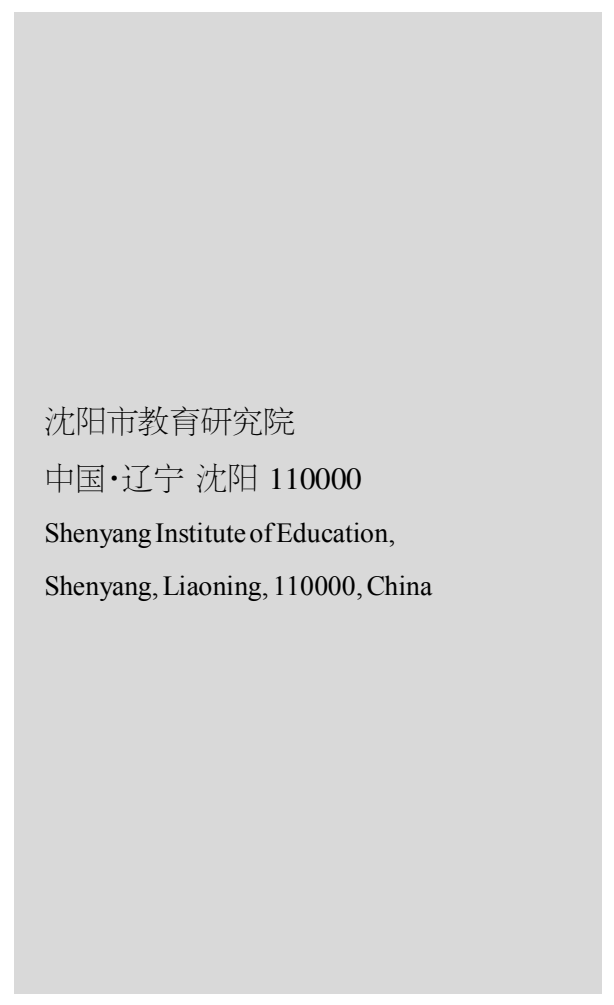

\section{1 背景}

中国职业院校技能大赛已成功举办了十年，积累了宝贵 经验, 已基本形成了“普通教育有高考, 职业教育有技能大赛” 的新局面。中国沈阳市政府落实《关于加快发展现代职业教育 的若干意见》精神, 弘扬 “劳动光荣、技能宝贵、创造伟大” 的时 代风尚, 成功举办了五年中国沈阳职业院校技能大赛, 同时邀 请沈阳经济区其他七城市中职学校学生参赛, 为新一轮沈阳 老工业基地全面振兴培养了高素质技术技能型人才。但是大 赛也给职业教育带来一些问题和发现一些问题，几年来在市 教育局领导的高度重视和精准指导下, 反复研究实践, 总结创 建了沈阳职业院校技能大赛 “四阶段六模块式” (即筹划、备 赛、赛程、赛果四个阶段,政策、团队、模式、手段、平台、成果 六个模块)赛事体系。

\section{2 设计依据}

中国共产党第十八次全国代表大会以来, 习近平总书记 多次深入职业院校考察, 并就职业教育做出重要批示、指示,
对加快发展中国职业教育提出明确要求, 强调要“高度重视、 加快发展”。2014 年 6 月, 国务院召开全国职业教育工作会 议,并印发《关于加快发展现代职业教育的决定》, 明确提出 “到 2020 年,形成适应发展需求、产教深度融合、中职高职衔 接、职业教育与普通教育相互沟通, 体现终身教育理念, 具有 中国特色、世界水平的现代职业教育体系” [1]。中国还规定, 从 2015 年起,将每年 5 月的第二周设为“职业教育活动周”,举 办全国职业院校技能大赛、中等职业学校“文明风采”竞赛, 营 造职业教育发展的良好氛围，受到各级行政部门和职业院校 的高度重视。解决为比赛而比赛, 这严重有悖于大赛的初衷, 严谨赛事体系的创建与实践显得尤为重要。

\section{3 体系内涵}

组委会遵循赛事的科学流程,明确赛事四个阶段,即: 谋 划赛事阶段、筹备赛事阶段、实施赛事阶段和应用及转化赛果 阶段,通过申请政府支持政策、组建赛事各类团队、创新比赛 模式、提供比赛环境与手段、搭建赛事各类平台、实践资源共 享六个模块的赛事体系建设, 将“工匠精神” 薪火相传 ${ }^{[2]}$ 。 


\section{4 体系实践}

\section{1 搭建赛事各类平台提高比赛质量}

通过搭建了“赛项培训平台”, 实现了“大赛训练引领常规 教学的目标”, 聘请省市国家级专家赛前安排开展了赛项培 训,普及赛项规程和比赛标准, 确保比赛质量; 搭建了“赛事层 层选拔平台” 实现锦标式训练向普惠式训练延伸目标; 搭建了 “专家大师执教平台”, 实现培养优秀团队、师徒传承的目标; 聘请省市国家级知名专家评委指导大赛、服务大赛; 搭建了 “企业技术支持平台”，实现校企共同开发专业标准和课程标 准、共建共享实习实训基地的目标, 为大赛提供技术支持, 确 保了赛事的安全与质量; 搭建了“行业、企业、学校联动平台” 实现优质就业目标,经过努力实现了比赛的“精彩、专业、廉 洁、安全”工作宗旨。

\section{2 应用及转化赛果实践资源共享扩大比赛效应}

为实现大赛资源共享, 以赛促教, 实现教学改革成果深 化, 各赛项制定了具体的赛项成果转化方案: 第一, 专业教学 资源包,组织企业和专家更新专业教学资源包,系统的梳理本 专业的培养目标、岗位需求、课程体系、核心知识点及历年竞

\section{(上接第 146 页)}

及时掌握学生每日健康信息、出行信息, 筛查出特殊学生群 体。根据学生的心理变化,及时召开多种心理辅导活动,利用 多种信息平台,做好学生的心理疏导工作。

目前, 大学生多因生活单调而产生焦躁情绪, 需引导大学 生合理规划自己的时间,制定切实可行的目标。要鼓励大学生 积极投身于志愿服务活动,做好社区防疫的宣讲员、社区防疫 的消毒员、社区防疫的登记员; 举办多种形式的抗疫活动, 通 过防疫海报创作、防疫诗歌创作等方式,使大学生切实参与到 防疫过程中,感受到自身的价值。

\section{3 做好学生就业指导者}

2020 年,全国普通高校毕业生 874 万人。因新型冠状病 毒肺炎的发生，使得世界经济受到严重的影响，就业岗位减 少, 就业形势严峻,毕业生的求职压力增大。高校辅导员要引 导毕业生正确认识当前的就业形势, 勇于接受挑战, 转变就业 观念,由被动变主动, 积极就业。

\section{1 加强思想政治引导,树立正确的就业观念}

高校辅导员要引导毕业生树立正确的就业观念，克服 “等、靠、要”的消极思想,善于抓住机遇, 化危为机, 变消极被 动为积极主动。要在就业工作中, 加强大学生的思想政治引 导,正确认识当前的就业形势; 进行清晰的自我定位, 明确自
赛考核内容与要点, 并结合技术发展趋势对未来的竞赛内容 设置进行权威预测。第二, 资源库建设, 依托沈阳职业院校技 能大赛, 将比赛试题、比赛现场视照片等资源统一整理, 发布 到沈阳职业院校技能大赛网站, 建议各专业将其添加到本专 业资源库建设中, 为广大职业院校师生提供在线学习交流的 平台。

\section{5 结语}

以中国共产党第十九次全国代表大会精神为指引谋划未 来职业教育改革发展, 完善职业教育和培训体系, 做好职业教 育创新发展的“施工图”, 按照“德技兼修、工学结合的育人机 制” “产教融合、校企合作的办学模式”的新要求, 聚焦“普惠、 健康” 主题, 深化职业教育教学改革, 实践和完善沈阳职业院 校技能大赛 “四阶段六模块” 赛事体系, 充分发挥大赛的示范 引领作用。

\section{参考文献}

[1]邓勇,朱文艳,王骁,等.以创新实践能力为本位的项目式人才培 养探索与实践[J].科技风,2020(14):273-274.

[2]陈步英.新时期高职计算机专业教学载体研究[J].中外企业家, 2020(13):157.

\section{己的职业发展规划。}

\section{2 实施精准指导,促进多方向就业}

高校辅导员要因人而异、分类施策, 精准指导学生就业。 针对考研的学生, 及时了解学生情况, 做好学生的复试、调剂 指导; 针对有出国留学意向学生,做好政策讲解、出国流程指 导; 针对有参军意向的毕业生,鼓励学生入伍参军; 针对就业 学生, 主动与企业对接, 为毕业生搭建平台; 针对创业学生, 做 好政策讲解和支持工作。疫情期间,政府和高校举办多种形式 的网络招聘会, 要鼓励学生积极参。要引导大学生将自身的发 展与祖国的发展相统一,鼓励大学生到基层就业, 实现人生价 值。高校辅导员要创新工作方式, 对毕业生进行精准指导, 促 进多方向就业,努力做好学生就业的指导者。

\section{4 结语}

疫情就是命令, 高校辅导员要闻令而动。在疫情期间,守 好责任田, 加强大学生的思想政治引导, 关注学生的心理健 康,做好学生的就业指导工作,全心全意做好服务工作。

\section{参考文献}

[1]中共中央政治局常务委员会召开会议研究新型冠状病毒感染 的肺炎疫情防控工作[N].人民日报,2020-02-13.

[2] 习近平. 团结合作是国际社会战胜疫情最有力武器. [J]. 求是, 2020(8). 